0

ن

ชิ

๙ิ

ஸै

'ִ

\title{
literárnych zbierok v rámci Európskej zbierky literárnych textov (ELTeC) na Slovensku a Ukrajine
}

Marek Debnár - Dmytro Jesypenko

DEBNÁR, M. - YESYPENKO, D.: Building of Complex and Representative Digital Literary Collections within the European Literary Text Collection (ELTeC) in Slovakia and in Ukraine SLOVENSKÁ LITERATÚRA 67, 2020, No. 6, p. 630 - 638

DOI: https://doi.org/10.31577/slovlit.2020.67.6.8

Marek Debnár - ORCID ID: 0000-0002-2879-6878

Dmytro Yesypenko - ORCID ID: 0000-0003-4720-8370

Key words: European Literary Text Collection (ELTeC), distant reading, national literatures, literary history, Slovakia, Ukraine

The paper deals with problems of building representative digital literary collections of national literatures, in particular those of Slovak and Ukrainian literatures, within the international context of the project European Literary Text Collection (ELTeC). At the beginning text characterizes the requirements laid down on creation and representativeness of such a national multilingual literary collection, which is established as a result of the project COST - Distant Reading for European Literary History (1840-1920) and analyzes various factors related to literary production in Slovakia and Ukraine. On the one hand, it includes a discrepancy between stronger partners of the project (socalled great European literatures) and weaker partners (so-called small literatures), on the other hand, the factor of accessibility of digital sources corresponding to the requirements of a project of this kind. 

analýza, štýlometria, rozpoznávanie autorstva či rozpoznávanie emócií, sa v posledných dvoch desatročiach stále viac dostáva do centra záujmu v interdisciplinárnom humanitnom výskume. Pozornost' sa mu venuje nielen v kontexte digitálnych humanitných vied (tzv. digital humanities), ale vo všetkých odboroch, ktorých výskum sa primárne opiera o interpretáciu textov, tradične označovanú ako close reading (literárna veda, historiografia, filozofia, etika, náboženské štúdiá a d'alšie). ${ }^{1}$

Na Slovensku a ani na Ukrajine, žial', nedisponujeme dostatočne rozsiahlou, t. j. relatívne kompletnou a spracovanou digitálnou literárnou zbierkou, aké sú bežné v zahraničí, kde okrem kompletných zbierok klasikov národných literatúr (napr. Archív stredovekej severskej literatúry na Univerzite v Bergene, britský Brownov korpus či kompletnee sprístupnené diela Williama Shakespeara a Jane Austenovej) môžeme nájst' aj vel'ké zbierky populárnej literatúry, akou je stanfordská FunFiction či desiatky autorských korpusov od Wittgensteinovho archívu v Nórsku, Mickiewiczovho v Pol'sku alebo obdobných projektov v susedných Čechách (napr. Korpus Karla Čapka či Korpus českého verša, ako aj špecializované digitálne archívy periodickej tlače). ${ }^{2}$

Určitá nádej na zmenu sa objavila v roku 2019, ked' sa Slovensko ako riadny člen a Ukrajina so štatútom „blízkeho suseda“ pripojili k medzinárodnému projektu COST Dištančné čítanie európskej literárnej histórie (1840 - 1920) (CA16204: Distant reading for European Literary History 1840 - 1920), ktorý vedú Christof Schöch (Univerzita Trier) a Maciej Eder (Pol'ská akadémia vied). Táto iniciatíva spája výskumné tímy z tridsiatich piatich krajín, čo predstavuje spolu viac ako sto účastníkov. ${ }^{3}$ Názov projektu odkazuje na nadnárodnú ideu

1 V tomto duchu prezentoval Franco Moretti aj svoj súčasný výskum na viacerých stretnutiach DR2 skupiny (DistantReading and Data-Driven Reseach in the History of Philosophy) na pôde Turínskej univerzity, ktorá je príkladom využitia korpusových metód práce s textom za hranicami jazykovedy a literatúry. Informácie o DR2 skupine dostupné na: https://dr2blog.hcommons.org. Na Slovensku tento prístup dlhodobo absentoval a objavil sa až v posledných rokoch, ked'ho začali vo svojich prácach využívat' autori hlásiaci sa k metódam a postupom digitálnych humanitných vied, napr. GOGORA, Andrej: The text mining of ethics and information technology. In: Communications. Scientific Letters of the University of Zilina, roč. 19, 2017, č. 1, s. 3 - 8; JUROVÁ, Jarmila - DEBNÁR, Marek: Interpretation of Values in the Epitaphs on the Tombstones of Old Jewish Cemetery in Bratislava, 2018. In: Communications. Scientific Letters of the University of Zilina, roč. 20, 2018, č. 1A, s. 71-79.V rokoch 2019 a 2020 vznikli aj prvé pôvodné slovenské monografie na tieto témy: DEBNÁR, Marek - GOGORA, Andrej: Digitálne trendy v súčasných humanitných vedách. Nitra : UKF, 2019; ZUMRÍK, Miroslav: Filozofické aspekty korpusovej lingvistiky. Bratislava : Veda, 2020. 2 V prípade ukrajinskej literatúry existuje pár výnimiek, napr. Ševčenkov portál (http://kobzar.ua/), ktorý obsahuje kompletnú zbierku čistých textov T. Ševčenka a skeny jeho rukopisov a tlačených vydaní. Na Slovensku zatial'nemáme takto vyčerpávajúco spracovaný autorský korpus.

3 Slovensko a Ukrajina sú krajiny, ktoré takpovediac naskočili na posledný vlak, ked’že sa projekt začal ešte v roku 2017 a obe krajiny sa doň zapojili až ku koncu roka 2019 (autori tohto článku sú zároveň zástupcami týchto krajín v projekte). V prípade Slovenska išlo najmä o nedostatok personálnych kapacít pre takýto projekt a v prípade Ukrajiny tažkosti súviseli so skutočnost'ou, že Ukrajina nemá štatút „,̌lenskej krajiny COST“, ale „krajiny blízkeho suseda“ (https://www.cost.eu/actions/CA16204/ \#tabs|Name:management-committee). 
„európskej literárnej histórie“, ale pri bližšom skúmaní vyjde najavo, že sa skôr zameriava na konkrétne európske literatúry a vztahy medzi nimi.

Úlohy a očakávané výstupy projektu sú podla oficiálnej stránky projektu nasledovné:

1. vybudovanie viacjazyčnej Európskej zbierky literárnych textov (ELTeC), ktorá bude obsahovat' okolo 2500 kompletných románových textov v najmenej desiatich rôznych jazykoch, čo umožní otestovat' výpočtové metódy a porovnat výsledky naprieč národnými tradíciami;

2. vytvorit' a zdielat inovatívne nástroje a metódy textovej analýzy prispôsobené viacjazyčnej literárnej tradícii Európy;

3. na základe výsledkov analýz prehodnotit základné koncepty v literárnej teórii a histórii. ${ }^{4}$

Ciele projektu sú teda v súlade so základnou koncepciou dištančného čítania Franca Morettiho a jeho predstavami o zmene paradigmy nášho chápania literárnych dejín. ${ }^{5}$ Spoločným menovatel'om prístupov a metód zjednotených pod pojmom dištančného čítania je využívanie elektronických textových korpusov v oblasti literárnej histórie. Cielom COST iniciatívy, ktorá sa usiluje o vybudovanie zbierky ELTeC, je svojou multilingválnou a viacnárodnou platformou odhalit' skryté prepojenia národných literatúr v širších európskych súvislostiach, ako aj reagovat' na kritikov koncepcie dištančného čítania, ktorí vyčítali tomuto prístupu anglocentrizmus. ${ }^{6}$ Voči týmto výčitkám sa síce ohradil aj sám Moretti, ${ }^{7}$ zbierka ELTeC je však v ovel'a väčšej miere zameraná na podporu inkluzívnosti týchto skúmaní, vrátane jazykovej.

Jadrom projektu je vytvorenie viacjazyčnej zbierky ELTeC, pričom táto vstupná fáza zahŕňa prípravu digitálnych zbierok národných literatúr, ktoré tvoria jeho podskupiny. Príprava jednotlivých častí zbierky znamená súbor povinností, ktoré sa u rôznych národných tímov rôznia. $\mathrm{V}$ niektorých literatúrach existujú vel'ké alebo dokonca rozsiahle zbierky vol'ne dostupných textov, ktoré vznikli $\mathrm{v}$ rámci predchádzajúcich výskumných projektov alebo $\mathrm{v}$ rámci digitalizačných aktivít národných knižníc. V prípade mnohých d'alších literatúr je však získavanie textov pre ELTeC vážnou výzvou. V každej národnej literatúre spravidla existuje obrovské množstvo románov publikovaných v periodikách alebo vo forme samostatných vydaní dostupných v knižniciach. Na rôznych internetových stránkach je tiež k dispozícii relatívne vela digitalizovaných verzií týchto publikácií. Pokial'však ide o romány kanonizované a prevedené do formátu čistých textových súborov, teda pripravené na rýchle a relatívne pohodlné zaradenie do korpusov podobných korpusom ELTeC, ich počet je pomerne nízky.

Viacjazyčnost' limituje aj kritériá zostavovania zbierky ELTeC. Na rozdiel od korpusov národných literatúr, ktoré sú šité na mieru konkrétnej tradície, medzinárodný projekt sa musí riadit' kritériami vyváženosti najmä preto, aby

4 Tento zoznam nie je úplný. Ciel'om projektu je tiež podporit odbornú prípravu a rozvoj začínajúcich riešitel'ov, podporit nové spoločné predkladanie návrhov do národných a európskych projektov a zabezpečit vyvážené zastúpenie mužov a žien v počitačových vedách a príbuzných oblastiach (https://www. distant-reading.net/about/objectives).

5 MORETTI, Franco: Conjectures on World Literature. In: New Left Review, 2000, č. 1, s. 54 - 68.

6 ARAC, Jonathan: Anglo-globalism? In: New Left Review, 2002, č. 16, s. 35 - 45.

7 MORETTI, Franco: Distant Reading. London : Verso, 2013. 
sa odstránila diskrepancia medzi vel'kými a malými literatúrami. Je zrejmé, že slovenská literatúra z obdobia rokov 1840 - 1920 neobsahuje tol'ko literárnych diel ako literatúra nemecká alebo francúzska, a preto je aj výber jednotlivých titulov značne limitovaný.

Základné formálne kritériá pre diela zaradené do zbierky sú nasledovné: Jazyk: pôvodné diela napísané v danom európskom jazyku, nie preklady. Štýl textov je definovaný ako fiktívne prozaické rozprávania (projekt nedefinuje žáner románu z hl'adiska literárnej teórie; väčšia pozornost' sa venuje vlastnostiam jednotlivých zložiek digitálnej zbierky na úrovni slov a spôsobu spracovania textov).

Časové obdobie: diela vydané knižne v rokoch 1840 - 1920.

Dížka textov: minimálna dížka jedného textu je desattisíc slov.

Publikovanie: v súčasnej fáze projektu sú preferované texty románov vydávané v knižných edíciách, je však možné zaradit' do zbierky aj romány vydávané časopisecky na pokračovanie.

Dostupnost': primárne je zámerom zaradit' do zbierky len vol'ne dostupné digitalizované texty alebo texty nepodliehajúce autorským právam, ktoré bádatelia - riešitelia projektu sami zdigitalizujú.

Na Slovensku existuje niekol'ko digitálnych zdrojov literárnych textov, od oficiálnych literárnych archívov knižníc (napr. digitálny archív Slovenskej národnej knižnice) ${ }^{8}$ cez verejné projekty postavené na dobrovol'níckej báze (napr. Zlatý fond denníka SME) ${ }^{9}$ až po neoficiálne súkromné internetové stránky, ktoré sa vyznačujú problematickými alebo nevysporiadanými vztahmi k autorským právam. Každý z týchto zdrojov je problematický a na vytvorenie slovenskej verzie zbierky ELTeC použitel'ný len v obmedzenej miere. Digitálne archívy knižníc disponujú väčšinou len skenmi bez alebo len s čiastočným (automatickým) optickým rozpoznaním znakov (OCR), čiže z jednotlivých stránok oskenovaných kníh je často potrebné extrahovat' samotný text pomocou špecializovaných softwarov (Transkribus, FineReader). Verejné projekty, akým je napr. Zlatý fond denníka SME, obsahujú len selektívne diela, pochádzajúce z rôznych vydaní (pričom často nejde o pôvodné texty, ale o texty v aktualizovanej jazykovej mutácii). Výsledný textový súbor rozsiahlejších próz je obyčajne výsledkom práce viacerých dobrovolníkov a vyznačuje sa chybovostou pri OCR. Tretia kategória sa zameriava prevažne na pirátske kópie populárnych literárnych diel a prekladov a týka sa len súčasnej slovenskej literatúry.

Prekvapením pri príprave ukrajinskej zbierky bolo, ako vel'mi sa ukázali ako užitočné súkromné iniciatívy vytvárania elektronických knižníc. ${ }^{10} \mathrm{Z}$ niektorých hladísk nielenže nezaostávajú, ale dokonca predstihujú podobné zbierky pripravené vel'kými inštitucionálnymi tímami národných knižníc. Je potrebné tiež poznamenat', že vel'ké množstvo publikácií ukrajinskej literatúry sa digitalizovalo v archívoch a knižniciach v Spojených štátoch amerických a Kanade.

8 https://www.snk.sk/sk/zbierky-a-zdroje/zbierky-literarneho-archivu-snk.html

9 https://zlatyfond.sme.sk

10 Napr. elektronické knižnice Chtyvo (https://chtyvo.org.ua/help/biblioteka/pro-nas) alebo Izbornyk (http://litopys.org.ua/). Je zaujímavé, že nájst' informácie o niektorých autoroch, ktorí iniciovali také rozsiahle (a svojím zámerom ušlachtilé) projekty, nie je l'ahké. Anonymita môže súvisiet' okrem iného so skutočnostou, že publikácie nie vždy dodržiavajú autorsko-právnu legislatívu. 
634 Neskôr sa vel'a z nich objavilo na vol'ne prístupných stránkach, vrátane stránok pre ukrajinských používatel'ov. ${ }^{11}$

Zostavovatelia čiastkových korpusov ELTeC, v tomto prípade tvorenom výberom sto diel z každej národnej literatúry v danom období (1840-1920), majú prístup k množstvu literárnych textov, či už v digitálnej alebo tlačenej podobe, ktoré je možné nazvat povinným čítaním. Tieto texty sa aktívne používajú vo výučbe a ich počet môže byt' ešte väčší ako počet, ktorý vyžaduje zostavenie národného súboru pre ELTeC. To však ešte neznamená, že je možné vytvorit zbierku jednoduchým preformátovaním povinného čítania podl'a pravidiel ELTeC. Texty v zbierkach ELTeC musia spĺňat niekol'ko kritérií, pričom klúčovým sa ukazuje vyvážený pomer kanonických a nekanonických textov. „Povinné čítanie“ pozostáva z kanonických literárnych diel, a preto by zostavovatelia národných zbierok ELTeC mali vyhl'adávat', skenovat', digitalizovat' a kódovat' aj množstvo d'alších nekanonických, menej známych textov.

Primárnym dôvodom je vyváženost' jednotlivých častí ELTeC, a to tak, aby tento základný výberový rámec bol reprezentatívnym celkom literatúry daného obdobia. Stanovit' pravidlá vyváženosti bolo pomerne tažké, ked'že jednotlivé európske literatúry nikdy neboli rovnako rozvinuté. Zatial'čo nemecká a francúzska literatúra udávali smerovanie vývinu literárneho diskurzu v Európe a zosobňovali to, čo v 19. storočí nazýval J. W. Goethe „svetovou literatúrou“, 12 menšie národy nedisponovali rovnako rozvinutou literárnou tradíciou. Pri tvorbe kritérií ELTeC bolo preto potrebné opierat' sa o určitý teoretický model, teda o podobný základ, aký nachádzame vo vyváženosti všeobecných jazykových korpusov, ktoré poznáme z počítačovej lingvistiky. Tá rozlišuje medzi špecializovanými jazykovými korpusmi, akým môže byt' napr. korpus medicínskych textov, a všeobecným korpusom, ktorý zastupuje jazyk ako celok. Hlavným účelom existencie všeobecných korpusov sú možnosti skúmania jazyka ako systému, t. j. opis jeho základných vlastností a poznávanie jeho reálneho fungovania. Dve podobné ambície nachádzame aj v digitálnych literárnych zbierkach. Ak chce nejaký literárny vedec študovat špecifiká poetického systému napr.v Shakespearových hrách, využije na to špeciálny korpus, ktorý pozostáva zo Shakespearových diel. Práve práca s ním, prípadne porovnávanie tohto korpusu s korpusom iného autora, mu umožní odhalit', potvrdit' či vyvrátit' určité predpoklady, ku ktorým sa nie je možné dopracovat' bežným čítaním. ${ }^{13}$ Pre takéto ciele sú zostavované a budované národné alebo špecializované digitálne literárne zbierky. Zámer vytvorit viacjazyčnú európsku literárnu zbierku ako ELTeC však takéto parciálne využitie prekračuje, pretože zmyslom takejto zbierky je preskúmat' systém literatúry podobným spôsobom,

11 K dispozícii je dokonca aj špeciálna elektronická knižnica obsahujúca skeny kníh publikovaných mimo Ukrajiny s názvom Diasporiana: https://diasporiana.org.ua/

12 K predstave svetovej literatúry, ako ju chápali J. W. Goethe v rozhovoroch s Eckermanom (1827) a o dvadsat' rokov neskôr K. Marx a F. Engels v Manifeste komunistickej strany (1848), sa F. Moretti stavia kriticky. Opisuje ju ako súdobé intelektuálne gesto limitované priestorom západnej Európy, presnejšie „nemeckými filológmi pracujúcimi s francúzskou literatúrou“ (MORETTI, Franco: Conjectures on World Literature. In: New Left Review, 2000, č. 1, s. 54).

13 Diela W. Shakespeara sa týkal aj výskum Petra Plecháča z Ústavu českej literatúry AV ČR, ktorý zaznamenal široký medzinárodný ohlas (PLECHÁČ, Petr: Relative contributions of Shakespeare and Fletcher in Henry VIII: An analysis based on most frequent words and most frequent rhythmic patterns. In: Digital Scholarship in Humanities, fqaa032, https://doi.org/10.1093/llc/fqaa032). 
ako všeobecné korpusy umožňujú skúmanie systému jazyka. Pre všeobecné tex- 635 tové korpusy platí, že pri ich tvorbe sa usilujeme o čo najväčšiu vyváženost', preto okrem vyrovnaného zastúpenia jednotlivých štýlov (publicistický, umelecký, vedecký) sa snažíme do korpusu zaradit' čo najviac textov z rôznych tematických oblastí určitej činnosti alebo poznania, tzv. domén. ${ }^{14}$ Je zrejmé, že tieto kritériá nie je možné jednoducho aplikovat' na literárne texty, preto je na mieste otázka, aké kritériá vyváženosti a reprezentatívnosti má teda ELTeC.

Hlavným kritériom je proporčné diachrónne zastúpenie diel vo fixne daných časových obdobiach podl'a roku prvého vydania diela:1840-1859, 186o-1879, 1880 - 1899, 1900 - 1920. Pod vyváženost'ou korpusu (zbierky) máme na mysli, že nasledujúce parametre sa budeme snažit' dodržat' pre každé časové obdobie, ako aj pre korpus ako celok, a to bez ohl'adu na to, kol'ko textov máme k dispozícii. Môže sa stat', že za určité obdobie budeme mat' nedostatok textov v niektorých kritériách, v inom zase bude potrebné urobit užší výber, ktorý budú mat' na starosti literárni historici orientovaní na dané obdobie. Zbierka v pilotnej verzii neobsahuje vel'ké množstvo textov, iba sto románov z každej literatúry, ktoré vyšli prvý raz v období rokov 1840 - 1920. ${ }^{15}$ Práve z týchto dôvodov sú pre každé obdobie klúčové percentuálne podiely.

Základné kritériá vyváženosti zbierky ELTeC sú nasledovné:

Autorský podiel: ideálne 9 autorov - 1 autor s tromi textami/románmi v každom časovom úseku (ak to nie je možné, v záujme zachovania vyrovnanosti zaradujeme do ELTeC len jeden text/román ${ }^{16}$ pre jedného autora).

Pohlavie autora: min. $10 \%$ a max. $50 \%$ by malo íst' o ženské autorky, pokial'je to vzhl'adom na časové obdobie možné.

DÍžka románov/textov: min. $20 \%$ budú zastúpené krátke romány (rozsah 10 ooo-50 ooo slov), min. $20 \%$ budú zastúpené dlhé romány (viac než 100 ooo slov), zvyšných $60 \%$ by mali tvorit' romány/texty štandardnej dížky, t. j. medzi 50 ooo a 100 ooo slovami.

Literárny kánon: min. 30 \% vysoko kanonizovaných textov, ktoré sa vyznačujú opakovanými vydaniami, čiže ide o „povinné čítanie“ daného obdobia. Naopak, min. 30 \% textov sú texty nezaradené do kánonu, t. j. texty, ktoré vyšli v d'alších vydaniach len zriedkavo alebo neboli nikdy znova vytlačené. Orientačná báza pre posudzovanie d'alších vydaní je, či text vyšiel opät' a kol'kokrát v časovom období 1970-2009. Dôvodom pre toto kritérium je najmä to, aby sa do zbierky dostali takisto texty, ktorým nebola z hl'adiska literárnych dejín určitej národnej literatúry

14 K tejto problematike viac v kapitole Bibliografická a štýlovo-žánrová anotácia dokumentov a textov v Slovenskom národnom korpuse. In: ŠIMKOVÁ, Mária - GAJDOŠOVÁ, Katarína - KMEŤOVÁ, Beáta - DEBNÁR, Marek: Slovenský národný korpus: Texty, anotácie, vyhliadávania. Bratislava : Jazykovedný ústav L'. Štúra SAV, Mikula, 2017.

15 Ďalšie romány, ktorých počet presahuje sto, sú zahrnuté v takzvaných „rozšírených zbierkach“. Aj ked'vydanie takýchto rozšírených zbierok v rámci ELTeC nie je plánované v najbližšej budúcnosti (aby sa nevytvoril nepomer medzi jednotlivými zbierkami), sú l'ahko dostupné a záujemcovia ich môžu použit' aj na iné účely (https://github.com/ COST-ELTeC).

16 Pojem románu v rámci ELTeC je definovaný vágne, iba ako fiktívny prozaický text. 
venovaná pozornost', čo v určitom zmysle ospravedlňuje nedostatočnost' a zjednodušenie $\mathrm{v}$ prístupe ku kanonizácii textov. ${ }^{17}$

Domnievame sa, že naplnenie týchto kritérií na menšom počte textov umožní formulovat' relevantné závery o širšej škále a obdobiach dejín národných literatúr. S určitým zjednodušením možno jeden román národnej literatúry považovat' za „predstavitel'a“ niekol'kých d'alších v komparácii s ostatnými národnými „predstavitel'mi“. Silnou stránkou koncepcie projektu ELTeC v zmysle vyváženosti je spojenie najvýznamnejších spisovatel'ov a druhoradých autorov, čím zbierka realizuje tézu Franca Morettiho o ,vel'kom nečítanom“ (the great unread). ${ }^{18}$ ELTeC navyše predstavuje nielen nekanonické texty $\mathrm{v}$ rámci konkrétnych európskych literatúr, ale aj „nekanonické literatúry“ ako celok, ktoré nie sú v západnom literárno-kritickom diskurze prakticky zastúpené. ${ }^{19} \mathrm{Na}$ výstup projektu - získanie porovnatel'ných korpusov pre rôzne literatúry - sú potrebné univerzálne princípy výberu textu a rovnaký štandard anotácií. Texty v zbierke ELTeC sú preto jednotne anotované a kódované vo formáte XML štandardami TEI. ${ }^{20}$ Výhodou je, že tieto anotácie robia konkrétni zástupcovia jednotlivých národných literatúr so svojimi tímami, ktorí sú odborníkmi na konkrétny literárny a kultúrny kontext. Môžu tak účinne a rýchlo vyriešit' zložité problémy, napríklad problémy spojené s historickými reáliami alebo so špeciálnymi jazykovými vlastnostami.

Jednotné štandardy a nevyhnutný odstup od konkrétnych literatúr však okrem pozitív vedie nevyhnutne aj k určitým stratám: „Ak chceme porozumiet' systému v jeho celistvosti, musíme sa zmierit’ s tým, že niečo stratíme“, ${ }^{21}$ napísal F. Moretti v programovom článku o dištančnom čítaní ešte v roku 2000 a platí to aj dnes. To, čo strácame, sú charakteristické a jedinečné vlastnosti menšinových kontextov, napríklad pri malých národných literatúrach je to ich viacjazyčnost'. Pretože v zbierke ELTeC je možné prezentovat' iba texty napísané v národných jazykoch, je zrejmé, že významné a často dôležité diela národnej literatúry napísané v inom jazyku sa vynechávajú. Na to dopláca najmä ukrajinská zbierka, a to $\mathrm{z}$ dôvodu, že ukrajinská literatúra obsahuje aj texty v ruštine, ale tiež v pol'štine a nemčine, ktoré napísali nielen autori „druhého sledu“, ale aj autori považovaní za národných klasikov. Napríklad romány Tarasa Ševčenka napísané v ruskom jazyku by z ukrajinskej zbierky ELTeC boli vylúčené. Existuje tiež obmedzenie týkajúce sa miesta vydania publikácie, ktoré by malo byt'v Európe. To znamená, že do zbierky sa nemôžu dostat' romány vydané napríklad v Severnej Amerike, a to ani v príslušnom časovom období a v príslušných národných jazykoch.

Ďalší problém, ktorý sa ukazuje v našom geografickom priestore, je, že zbierka ELTeC uprednostňuje knižné verzie, t. j. samostatné dobové vydania, pred

17 Koncepcia kanonicity je spojená s počtom (opakovaných) publikácií diel za posledných niekol'ko desatročí. Je to zjavné zjednodušenie, pretože počet vydaní nemôže slúžit' ako spolahlivý ukazovatel' kanonicity a dokonca ani popularity určitého diela.

18 F. Moretti si termín vypožičal od Margaret Cohenovej, ale pre ňu znamenal skôr „literárny archív“, neprečítané zdroje na štúdium literárnych diel (KHADEM, Amir: Annexing the Unread: A Close Reading of „Distant Reading“. In: Neohelicon, roč. 39, 2012, s. 410).

19 Viac k výkladom nekanonicity Khadem, c. d., s. 418.

20 Pokyny pre kódovanie: https://distantreading.github.io/Schema/eltec-1.html; https://distantreading. github.io/Schema/eltec-2.html

21 MORETTI, Franco: Conjectures on World Literature. In: New Left Review, 2000, č. 1, s. 54 - 68. Cit. podla MORETTI, Franco: Distant Reading. London : Verso, 2013, s. 49. 
seriálovými publikáciami v periodikách, kde často vychádzali dlhšie prózy na pokračovanie; vystupuje to ako problém v ukrajinskej i slovenskej zbierke. Takisto je žiaduce mat' prvé vydanie románu, hoci táto podmienka patrí k tzv. mäkkým podmienkam - snaha držat' sa prvého vydania značne zvyšuje pracovnú zátaž. Redakčná prax zostavovania zbierok zo slovanských literatúr obyčajne uprednostňovala texty neskorších vydaní; spravidla sa vyberalo posledné vydanie za života autora, ktoré obsahuje jeho konečné zámery. ${ }^{22}$ Väčšina vol'ne dostupných ukrajinských a slovenských digitálnych textov preto predstavuje presne takúto verziu. To znamená, že zostavovatelia zbierok musia diela skontrolovat' a porovnat' ich s verziami prvých vydaní, podl'a ktorých je potrebné urobit' menšie, avšak niekedy významné zmeny. Nie je správne zazlievat' projektu toto posledné obmedzenie, pretože ide o všeobecnejšiu otázku. Katherine Bode výstižne poznamenala, že dôsledné čítanie, a teda aj dištančné, odmieta skutočnost', že literárne diela nie sú jediným a stabilným textom. ${ }^{23}$ Výskumní pracovníci, rovnako ako čitatelia a vydavatelia, sa zvyčajne chcú zaoberat' presne týmto jediným, klasickým, autentickým kanonickým textom, ktorý takmer nikdy neexistuje.

Aký je teda aktuálny stav zbierky ELTeC ? Od novembra 2020 sa zverejňujú na platforme Zenodo jednotlivé národné zbierky, ktoré spĺnajú kritériá a obsahujú minimálne pät'desiat textov. ${ }^{24}$ Pôvodne malo íst' o kolekciu prvých desiatich národných literatúr, existujú však dôvody domnievat' sa, že ambiciózna úloha pripravit' viac ako desat' reprezentatívnych čiastočných zbierok s polovičným počtom románov bude splnená do konca roka 2020 (projekt sa končí v novembri 2021). Aktuálny stav slovenskej a ukrajinskej zbierky ELTeC je taký, že slovenské aj ukrajinské zastúpenie v projekte COST sa usiluje napriek vyššie opísaným problémom s digitálnymi zdrojmi spracovat' a pripravit' svoje národné verzie zbierok ELTeC. V prípade Slovenska prípravu výrazne stažuje absencia kvalitných digitálnych zdrojov, teda profesionálne zostavenej fulltextovej zbierky slovenskej literatúry, ktorá by sa dala v tom to prípade využit'. Na jej vytvorenie vo verzii značne rozšírenej a prispôsobenej slovenským špecifikám bol na jeseň 2020 v rámci výzvy Agentúry pre vedu a výskum podaný spoločný projekt troch pracovísk, dvoch ústavov SAV a jedného univerzitného pracoviska. Podpora projektu by výrazne napomohla nielen k skvalitneniu digitálneho výskumu slovenskej literatúry, ale aj k zapojeniu slovenských vedcov do európskych a širších medzinárodných výskumných infraštruktúr v rámci dištančného čítania a digitálnych humanitných vied.

Štúdia je výstupom grantového projektu MVTS SAV COST Action CA 16204: Distant Reading for European Literary History (1840-1920). Zodpovedný riešitel: Mgr. Marek Debnár, PhD. Doba riešenia: $2019-2021$

22 Princíp editio ultima (posledné autorské vydanie) dominoval nielen vo vedeckej redakcii ukrajinskej literatúry, ale vo väčšine slovanských literatúr (YESYPENKO, Dmytro: Printed and Digital Wor(l)ds: Retrospectives and Perspectives of Scholarly Editing in Slavic Countries. In: Canadian Slavonic Papers, roč. 62,2020 , č. 1 , s. 50,60$)$.

23 BODE, Katherine: Abstraction, Singularity, Textuality: The Equivalence of "Close“ and „Distant“ Reading. In: BODE, Katherine: A World of Fiction: Digital Collections and the Future of Literary History. Ann Arbor : University of Michigan Press, 2018, s. 33.

24 https://distantreading.github.io/ELTeC/ 
ARAC, Jonathan: Anglo-globalism? In: New Left Review, 2002, č. 16, s. $35-45$.

BODE, Katherine: Abstraction, Singularity, Textuality: The Equivalence of „Close“ and „Distant" Reading. In: BODE, Katherine: A World of Fiction: Digital Collections and the Future of Literary History. Ann Arbor : University of Michigan Press, 2018, s. 16-35.

COHEN, Margaret: Narratology in the Archive of Literature. In: Representations, zv. 108, 2009, č. 1, s. $51-75$.

DEBNÁR, Marek - GOGORA, Andrej: Digitálne trendy v súčasných humanitných vedách. Nitra : UKF, 2019.

GOGORA, Andrej: The text mining of ethics and information technology. In: Communications. Scientific Letters of the University of Zilina, roč. 19,2017 , č. 1 , s. $3-8$.

JUROVÁ, Jarmila - DEBNÁR, Marek: Interpretation of Values in the Epitaphs on the Tombstones of Old Jewish Cemetery in Bratislava, 2018. In: Communications. Scientific Letters of the University of Zilina, roč. 20, 2018, č. 1A, s. $71-79$.

KHADEM, Amir: Annexing the Unread: A Close Reading of „Distant Reading“. In: Neohelicon, roč. 39, 2012, s. 409-421.

MORETTI, Franco: Conjectures on World Literature. In: New Left Review, 2000, č. 1 , s. $54-68$.

MORETTI, Franco: Distant Reading. London : Verso, 2013.

MORETTI, Franco: Grafy, mapy, stromy - Abstraktni modely literární histórie. Prel. Olga Čaplyginová. Praha : Karolinum, 2014.

MORETTI, Franco: Graphs, Maps, Trees: Abstract Models for a Literary History. London : Verso. 2005.

NEWMAN, Mark: The Structure and Function of Complex Networks. In: SIAM Review, roč. 45, 2003, č. 2, s. 167 - 256. Dostupné na: http://epubs.siam.org/doi/pdf/10.1137/S003614450342480

ŠIMKOVÁ, Mária - GAJDOŠOVÁ, Katarína - KMEŤOVÁ, Beáta-DEBNÁR, Marek: Slovenskýnárodnýkorpus: Texty, anotácie, vyhladávania. Bratislava : Jazykovedný ústav L'. Štúra, Mikula, 2017.

YESYPENKO, Dmytro: Printed and Digital Wor(l)ds: Retrospectives and Perspectives of Scholarly Editing in Slavic Countries. In: Canadian Slavonic Papers, roč. 62, 2020, č. 1, s. 45 - 66 .

ZUMRÍK, Miroslav: Filozofické aspekty korpusovej lingvistiky. Bratislava : Veda, 2020.

\section{Elektronické zdroje}

PLECHÁČ, Petr: Relative contributions of Shakespeare and Fletcher in Henry VIII: An analysis based on most frequent words and most frequent rhythmic patterns. In: Digital Scholarship in Humanities, fqaa032, DOI: https://doi.org/10.1093/llc/fqaa032

Mgr. Marek Debnár, PhD.

Ústav slovenskej literatúry SAV

Dúbravská cesta 9

84104 Bratislava

Slovenská republika

E-mail: Marek.Debnar@savba.sk

\section{Dr. Dmytro Yesypenko}

Taras Shevchenko Institute of

Literature

National Academy of Sciences

of Ukraine

4 Mykhaila Hrushevskoho Street

Kyiv 01001

Ukraine

E-mail: dm.yesypenko@gmail.com 